\title{
Correction to: Fundamental mentality in a physical world
}

\section{Christopher Devlin Brown ${ }^{1}$}

Published online: 9 November 2020

() Springer Nature B.V. 2020

\section{Correction to: Synthese https://doi.org/10.1007/s11229-020-02914-7}

The original article has been corrected. Reference Chalmers (2010) was removed from the reference section by mistake and has now been added.

\section{Reference}

Chalmers, D. (2010). The character of consciousness. Oxford: Oxford University Press.

Publisher's Note Springer Nature remains neutral with regard to jurisdictional claims in published maps and institutional affiliations.

The original article can be found online at https://doi.org/10.1007/s11229-020-02914-7.

$\triangle$ Christopher Devlin Brown

christopher.devlin.brown@gmail.com

1 Bilkent University, Ankara, Turkey 